\title{
The impact of small- and medium-sized family firms on economic growth
}

\section{Esra Memili, Hanqing Fang, James J. Chrisman \& Alfredo De Massis}

\section{Small Business Economics}

An Entrepreneurship Journal

ISSN 0921-898X

Volume 45

Number 4

Small Bus Econ (2015) 45:771-785

DOI 10.1007/s11187-015-9670-0

\section{SMALL}

\section{BUSINESS}

ECONOMICS

An Entrepreneurship Journal

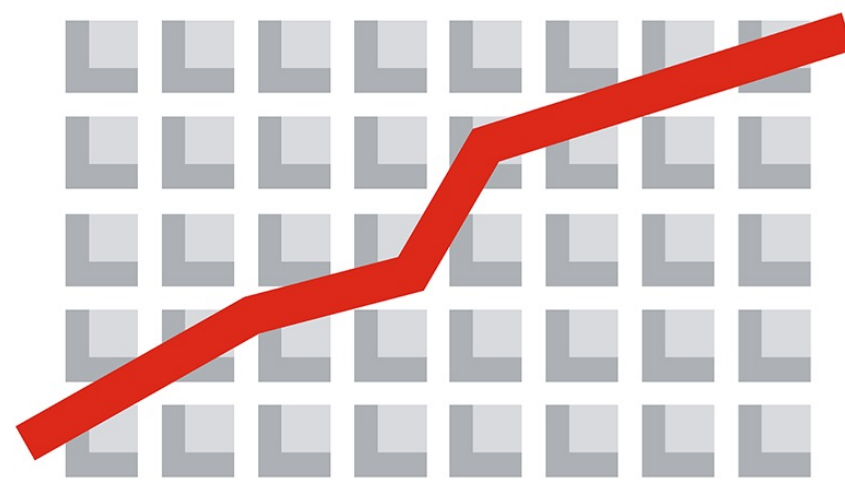

Volume 45 No. 4 December 2015 
Your article is protected by copyright and all rights are held exclusively by Springer Science +Business Media New York. This e-offprint is for personal use only and shall not be selfarchived in electronic repositories. If you wish to self-archive your article, please use the accepted manuscript version for posting on your own website. You may further deposit the accepted manuscript version in any repository, provided it is only made publicly available 12 months after official publication or later and provided acknowledgement is given to the original source of publication and a link is inserted to the published article on Springer's website. The link must be accompanied by the following text: "The final publication is available at link.springer.com". 


\title{
The impact of small- and medium-sized family firms on economic growth
}

\author{
Esra Memili • Hanqing Fang • \\ James J. Chrisman • Alfredo De Massis
}

Accepted: 14 July 2015/Published online: 23 July 2015

(C) Springer Science+Business Media New York 2015

\begin{abstract}
Drawing on family business studies and the knowledge-based view of economic growth, we develop and test a model of how the prevalence of small- and medium-size enterprises (SMEs) under family control affects economic growth. Specifically, we propose there is an inverted U-shaped relationship between family SMEs' proportional representation and economic growth owing to their relative strengths and limitations vis-à-vis non-family SMEs. Using state-level data from the US between 2004 and 2010, we find support for our hypothesis and the underlying contention that economic growth is maximized when an economy includes a balanced mix of family and non-family SMEs.
\end{abstract}

\section{E. Memili}

Bryan School of Business and Economics, University of North Carolina at Greensboro, PO Box 2617, Greensboro, NC 27402-6170, USA

e-mail: e_memili@uncg.edu

H. Fang · J. J. Chrisman

Department of Management and Information Systems, Mississippi State University, Mississippi State,

MS 39762-9581, USA

e-mail: hf133@msstate.edu

\section{J. J. Chrisman}

e-mail: jchrisman@business.msstate.edu

H. Fang

China Small and Medium Business Research Institute,

Zhejiang University of Technology, Zhejiang, China
Keywords Family business - Economic growth Family firms · SMEs $\cdot$ Knowledge asymmetry

JEL Classifications D82 asymmetric information · L26 entrepreneurship · O47 empirical studies of economic growth $\cdot$ O51 US

\section{Introduction}

Economic growth is defined as the increase in the output of an economy, reflecting its capacity to produce goods and services (Barro 1991). Theories of economic growth largely recognize that newly created and smallto medium-size enterprises (SME) (i.e., firms with

\section{J. J. Chrisman \\ Centre for Entrepreneurship and Family Enterprise, University of Alberta, Edmonton, Alberta, Canada}

\author{
A. De Massis $(\bowtie)$ \\ Centre for Family Business, Department of \\ Entrepreneurship, Strategy and Innovation, Lancaster \\ University Management School, \\ Bailrigg, Lancaster LA1 4YX, UK \\ e-mail: a.demassis@lancaster.ac.uk
}


$<500$ employees) are the engines of economic growth, as they create jobs, spark competition, and promote innovation and knowledge spillovers, all of which stimulate economic growth in a society (Acs and Szerb 2007; Audretsch 2007; Rothwell and Zegveld 1982; Schumpeter 1934).

Research has indicated that family involvement among SMEs is prevalent (Schulze and Gedajlovic 2010; La Porta et al. 1999). ${ }^{1}$ Studies also show that family SMEs have different organizational goals, resources, risk-taking propensities, and investment horizons from non-family SMEs (e.g., Becchetti and Trovato 2002; Donckels and Frochlich 1991; Kotlar et al. 2014; Sharma, Chrisman and Chua 1997). Studies have underscored family SMEs' prevalence in local economies (e.g., Astrachan and Shanker 2003; Chang et al. 2008; Shanker and Astrachan 1996), yet how and to what extent the prevalence of family SMEs contribute to economic growth is still largely unknown. Thus, a better understanding of how the prevalence of family SMEs influences economic growth will contribute to both family business research and public policy making (Audretsch 2007).

Prior literature draws attention to both reinforcing (e.g., Astrachan and Shanker 2003; Benedict 1968; Bjuggren et al. 2011; Khalaf and Shwayri 1966; Westhead and Howorth 2007) and retarding effects (e.g., Morck et al. 1998; Morck and Yeung 2003, 2004) of family firms on economic growth around the world. By drawing on family business studies and the knowledge-based view of economic growth, we examine the impact of the prevalence of family SMEs on economic growth at the state level in the USA. We chose to study the relationship between the prevalence of family firms and economic growth in the USA for the following reasons. First, idiosyncratic strategies, variations in knowledge stocks, and high competition that would stimulate imitation are characteristic of the US market (Knott 2003). Thus, the USA is an appropriate context to test our theory centered in knowledge heterogeneity and knowledge spillover. Second, there is a sufficient disparity in economic growth and types of firms across the states in the USA to make our analysis meaningful. Third, there is

\footnotetext{
${ }^{1}$ Family firms are firms where the family holds a significant ownership stake, is involved in firm governance, and has a vision for how the firm will benefit the family, potentially across generations (Bennedsen et al. 2010; Chua et al. 1999).
}

nevertheless a reasonable degree of homogeneity in other factors, such as culture and legal regimes that might influence economic growth, to ensure that the possible confounds to our analysis are minimized. Finally, the size of the USA ensured that we were able to collect enough data for our study.

We suggest that the prevalence of family firms will have an inverted U-shaped relationship with economic growth. Put differently, we theorize that economic growth is optimized when it includes both family and non-family firms. The contention that a mix of family and non-family SMEs is more conducive for economic growth than either type of firm alone is consistent with the idea that a certain degree of heterogeneity and variety of organizational forms is beneficial to the productive potential of a regional economy (Knott 2003; Wennekers and Thurik 1999). The findings of our analyses based on longitudinal data obtained from the Small Business Development Center (SBDC) program, US Census, and US Bureau of Economic Analysis support our hypothesis.

Our study contributes to the literature in the following ways. First, we extend the knowledge-based view of economic growth by explicitly recognizing family involvement as an important dimension of heterogeneity among SMEs, which is expected to increase economic growth. Second, we consider both the strengths and limitations of family SMEs to argue that the impact of family SMEs is neither purely positive nor negative, but rather that the composition of SMEs is what matters in the economy. Third, the results of our study contribute to the literature by providing support for the hypothesis that there is an inverted U-shaped relationship between the prevalence of family SMEs and economic growth. In short, we contribute to an improved understanding of the role of family firms in promoting economic growth.

In the remainder of this paper, we present our theory, hypothesis, methodology, and results, followed by a discussion of the implications and limitations of our study.

\section{Theoretical background and hypothesis}

Numerous studies indicate the importance of SMEs to economic growth (e.g., Thurik and Wennekers 2004; Wennekers and Thurik 1999). The literature often highlights that SMEs differ from their large peers in 
Table 1 Demographic characteristics of family and non-family firms in sample

\begin{tabular}{|c|c|c|c|c|}
\hline & \multicolumn{2}{|c|}{ Family firms (FF) } & \multicolumn{2}{|c|}{ Non-family firms (NFF) } \\
\hline & Mean & S.D. & Mean & S.D. \\
\hline Age & 10.64 & 14.68 & 9.83 & 12.87 \\
\hline Employment & 10.65 & 27.57 & 10.25 & 28.92 \\
\hline Sales (thousand dollars) & 913.82 & 2930.03 & 992.84 & 3571.10 \\
\hline Manufacturing industry & 0.13 & 0.33 & 0.14 & 0.34 \\
\hline Service industry & 0.26 & 0.44 & 0.31 & 0.46 \\
\hline Other industries & 0.61 & 0.49 & 0.55 & 0.50 \\
\hline Sample size & 18,263 & & 21,700 & \\
\hline
\end{tabular}

terms of job creation, strategic flexibility, and innovation (Audretsch 2007). In turn, economies with more SMEs are found to be more competitive and with higher growth rates than those with fewer SMEs (Audretsch et al. 2006).

Recent research acknowledges that besides the direct effects caused by their inherent attributes, SMEs may also have indirect effects on economic growth due to competition and cooperation among SMEs or between SMEs and larger organizations (Audretsch 2007). In this regard, studies are starting to recognize the roles of knowledge asymmetries and knowledge spillovers in the interactions between firms (Acs et al. 2009; Audretsch and Feldman 1996). Knowledge asymmetry refers to the fact that market competitors often vary with respect to their stocks of knowledge as well as their recognition and usage of those stocks (Audretsch 2007). Knowledge spillover suggests that given variant knowledge stocks in a market, knowledge may spillover from those with high stocks to those with low stocks (Agarwal et al. 2007). In turn, knowledge spillovers may spur competition and innovation (Agarwal et al. 2004; Knott 2003).

Knott (2003) further argues that the presence of a few large corporations with numerous small firms brings variations in knowledge stocks, suggesting that the superior knowledge stocks in large firms may spill over to small firms, thereby improving their R\&D productivities. Indeed, to maintain a sustainable economy, it is important to have an "optimal proportion" of both large and small firms (Wennekers and Thurik 1999; Thurik and Wennekers 2004). While this line of research largely focuses on firm size, Knott (2003) also notes that other dimensions of heterogeneity such as national origin (Acs et al. 2007), functional competence (Hoopes et al. 2003), and firm age (Agarwal et al. 2004) can lead to knowledge asymmetry among market competitors. This then fuels diffusion of knowledge across firms (knowledge spillover), which subsequently erodes the position of market leaders and stimulates competition in the creation of knowledge. In sum, an economy with heterogeneous firms is generally more innovative and more competitive, both of which positively relate to economic growth. As discussed below, we extend this reasoning to theorize that heterogeneous governance structures, specifically those based on family and nonfamily control, also facilitate economic growth.

\subsection{Family SMEs and economic growth}

Although scholars generally agree on the prevalence of the family form of organization (Astrachan and Shanker 2003; Chang et al. 2008; Gersick et al. 1997; Tagiuri and Davis 1996), the link between the prevalence of family firms and economic growth is still not clear. Given the distinctions in their behaviors and performance, it follows that the impact of family and non-family firms on economic growth is also likely to differ. Family firms have both functional (e.g., resource providing and cost reducing) and dysfunctional characteristics (e.g., innovation aversion) that do not necessarily depend upon differences in size, age, or industry, which are instead thought to be a function of the unique characteristics of family firms (e.g., Gedajlovic and Carney 2010; Pollak 1985). Indeed, as shown in Table 1, family and non-family firms are not greatly dissimilar in these characteristics.

\subsubsection{Reinforcing effects of family involvement in SMEs}

The effects of family firm prevalence on economic growth can be either reinforcing or retarding, 
depending on the mix of family and non-family firms in an economy. In this section, we argue that family involvement in SMEs may have several positive effects on firm performance and economic growth. In the next section, we discuss their retarding effects.

First, family involvement can provide the resources and capital that facilitate venture creation and success (c.f., Habbershon and Williams 1999). Such resources may take the forms of human capital (Dyer 2003), social capital (Arregle et al. 2007), and physical and financial assets (Aldrich and Cliff 2003), which ventures created by entrepreneurs without family ties are less likely to possess or be able to imitate. For example, recent research suggests that teams composed of couples are more likely to achieve first sales than those composed of unrelated partners or individuals with biological linkages (Brannon et al. 2013). However, biologically linked teams that made large financial investments in a venture were also found to be successful. Furthermore, family involvement may provide survivability capital for the firm (Sirmon and Hitt 2003) and increase the stability of the economy, especially in scarce environments (Carney 2005).

Second, owing to a desire for transgenerational sustainability, family firms tend to be oriented toward the long term, which provides them with advantages in terms of continuity, perseverance, and self-control (James 1999; Lumpkin and Brigham 2011). Higher and steadier long-term performance is often the consequence if concerns for the past and future do not obscure the needs of the present (Le Breton-Miller and Miller 2011)

Third, family owners and managers tend to be more parsimonious in the use of firm assets because they are spending their own money (Carney (2005). Furthermore, family control can reduce agency costs resulting from the separation of ownership and management, because owners (principals) and managers (agents) are either the same individuals or are members of the same family (e.g., Fama and Jensen 1983). Although some scholars point out that asymmetric altruism among members of the owning family may lead to different sorts of agency problems (e.g., Schulze et al. 2001), the received wisdom is that aggregate agency costs are lower in family SMEs than non-family SMEs (Chrisman et al. 2004). Although there is a tendency to focus on how increases in effectiveness through product innovation increases economic growth, higher levels of productive or transaction efficiencies can achieve the same end (Chang et al. 2008; Schumpeter 1934).

\subsubsection{Retarding effects of family involvement in SMEs}

Since family SMEs have unique advantages, the growth of an economy that relies excessively upon non-family SMEs is likely to be stifled. Nevertheless, an excessive reliance on family SMEs is not optimal either: Family SMEs have some offsetting limitations that suggest they are not a panacea. In addition, these retarding effects of family involvement are more salient when non-family SMEs are absent. Thus, consistent with the idea that a certain degree of heterogeneity and variety of SMEs is beneficial to the productive potential of a regional economy (Knott 2003; Wennekers and Thurik 1999); in this section, we argue that economic growth is maximized when there is a balanced mix of family and non-family SMEs.

In general, family SMEs are less innovative compared to non-family SMEs (Chrisman et al. 2015; Classen et al. 2014; De Massis et al. 2013a; GómezMejía et al. 2011) because of inertia, lack of specialized talent, emotional ties with existing products and assets, traditions restricting change, reluctance to risk the family's reputation, unwillingness to use external financing, and inefficient use of firms resources when there is high emphasis on preservation of socioemotional wealth (e.g., König et al. 2013; Gómez-Mejia et al. 2010; Schepers et al. 2014). As revealed by Carney (2005), when technological development is critical for success, family firms often face difficulties. Hence family SMEs, in turn, can hamper economic growth.

It should be noted that the retarding effect (less innovation) becomes more salient when family SMEs become more dominant in an economy for two reasons. First, due to their reluctance to innovate, family firms are less likely to generate new knowledge. Indeed, family firms are often stuck in their traditional routines and approaches, being slower in recognizing the emergence of new technologies (König et al. 2013). Hence, knowledge asymmetry among firms becomes limited when family involvement is dominant in SMEs. Second, from a knowledge-based view, family SMEs are endowed with tacit, non-codifiable and socially complex knowledge, which is difficult to be learned or imitated by competitors (Cabrera-Suárez et al. 2001). In addition, emotional ties among family members and strong identification with the firm often restrict the mobility 
of employees, particularly family employees, in family business (Colombo et al. 2014; Gómez-Mejía et al. 2011). Put differently, knowledge spillover is further limited due to labor immobility in family SMEs. Taking both together suggests that even if family SMEs are heterogeneous regarding their knowledge stocks, knowledge spillover between family SMEs is still less likely due to limited knowledge mobility.

\subsubsection{Interaction between family and non-family SMEs}

Given family SMEs' reinforcing and retarding effects on economic growth, one would intuitively assume that a moderate level of family SMEs' prevalence in a local economy would maximize economic growth. Family firms should be more resilient to economic shocks and better able to overcome liabilities of newness owing to their unique access to human, social, and financial capital through family involvement (Chrisman et al. 2011). The combination of ownership and control should also reduce agency costs, increase the importance of sustainable longterm performance, and yet provide greater flexibility to make rapid decisions (Carney 2005). On the other hand, non-family SMEs should be more innovative and have higher levels of knowledge stocks. This, in combination with weaker knowledge mobility, barriers in non-family firms can provide the knowledge spillovers needed to instigate innovation in family SMEs, especially when their survival is threatened. Theory suggests that family firms should be better implementers of discontinuous technologies than nonfamily firms (König et al. 2013); indeed, research has found that when performance is below aspirations, family firms increase their $R \& D$ investments more than non-family firms (Chrisman and Patel 2012; Gómez-Mejía et al. 2011; Kotlar et al. 2014).

Thus, based on the idea that family and non-family firms have countervailing strengths and weaknesses and that heterogeneity stimulates innovation and economic growth (Knott 2003), we propose that a nonlinear inverted U-shaped relationship will exist between the proportion of family SMEs and a region's economic growth.

Hypothesis There is an inverted U-shaped relationship between the proportion of family SMEs in an economy and economic growth.

\section{Methodology}

To test our hypothesis, we collected secondary data from a variety of sources, including the US Census, US Bureau of Economic Analysis and National Vital Statistics System. Our primary information source for estimating the proportion of family SMEs is the Small Business Development Center (SBDC) Program in the USA. SBDCs exist in each of the states and territories in the USA, and their client base has generally been found to be representative of the population of such firms (Chang et al. 2008; Chrisman et al. 2012). Hence, SBDC clients are an appropriate sampling frame for investigating the prevalence of family firms and their effects on local economies. The SBDC conducts annual surveys on the economic impact of its counseling services, which are sent to the entire population of its clients in the USA who received at least $5 \mathrm{~h}$ of assistance.

There were 50,067 responses to the SBDC's surveys over the period from 2005 to 2009. The effective response rate was approximately $18 \%$. Excluding clients who did not start business left us with 39,963 observations. In order to test for potential non-response bias, the respondents are divided into early and late respondents based on when they responded to the questionnaire. There were no statistically significant differences between these groups of respondents based on $t$ tests; therefore, non-response bias does not appear to be a significant problem in this study (Kanuk and Berenson 1975; Oppenheim 1966).

It should be noted that we aggregate our independent variable according to state- and year-level observations. In order to ensure an adequate number of responses per state and per year, we set response thresholds from each state for each year. For instance, for our primary analysis, we exclude state-year observations with $<50$ responses with complete data. After excluding observations with missing data, we obtained 121 longitudinal state-year observations for further analysis.

\subsection{Dependent variable}

We use the year-on-year log difference in gross state product (GSP) per capita (measured in thousand dollars) as the measure of economic growth in a state for the years 2006-2010. The log difference of GSP per capita (measured in thousand dollars) captures the growth or decline of the regional economy. We also use 
the percentage change in GSP per capita and the absolute value of GSP per capita in our robustness tests.

\subsection{Independent variable}

The independent variable in our analysis is the prevalence of family SMEs in each state for each year analyzed. Two steps were necessary to make this estimate because the source of ownership is not tracked in any publicly available data source. Even the SBDC does not directly provide any information on the prevalence of family firms per state and per year. Therefore, we use the aggregate of firm-level data in the SBDC survey database to create measures of family firm density per state per year (Chang et al. 2008).

In the first step, we classified each firm as a family or non-family SME. We based the classification on family ownership, family management, and intention for intra-family succession to distinguish family from non-family firms (e.g., Chrisman et al. 2012). The SBDC survey includes questions regarding the proportion of the firm owned by the founder and other family members, number of family managers, and whether the family holds an intention for intra-family succession. Following Chua et al. (1999), we operationalized family firms as those with a minimum of $50 \%$ family ownership, at least one family manager and a manifest intention for intra-family succession. As will be further explained below, we also operationalized family firms by ownership only, using thresholds of 50 and $100 \%$ family ownership, for robustness tests.

Second, the prevalence of family SMEs in each state per year was calculated by dividing the number of family SMEs by the number of all firms. The proportion of family firms per state and per year was used as the independent variable. As noted above, to obtain an optimal balance between the number of responses per state and the size of the sample available for analysis, we include only those states where at least 50 responses were obtained in a given year. We chose 50 as the cutoff because it maximized the trade-off between the number of states included and the number of firms per state. Robustness tests were conducted using 40 and 60 respondent minimums. A 1-year lag was used between the time period to measure the independent variable and the time period for the dependent variable; hence, our independent variables cover the period from 2005 to 2009. After these two steps, it is found that the proportion of family firms in each state ranged from 18.2 to $66.7 \%$, with a mean of $43.7 \%$ and standard deviation of $10.9 \%$. Given the restrictions used to define family firms, these percentages are lower than might be expected. However, when we relaxed the criteria used to define family firms in the robustness tests, the proportion of family firms increased, similar to what has been seen in other studies (e.g., Chang et al. 2008; Shanker and Astrachan 1996; Westhead and Howorth 2007).

We subsequently squared the variable measuring the prevalence of family SMEs and used that as an additional independent variable in order to test our hypothesis concerning the nonlinear, inverted U-shaped relationship between family SMEs and economic growth.

\subsection{Control variables}

We used several controls in our analysis. Except where specified, each control was measured 1 year prior to the dependent variable. The size of a state's population may impact economic growth as larger populations offer more business opportunities (Chrisman et al. 1992). We used the number of residents per state and per year as the measure of population, obtained from the US Census. This variable was transformed using the natural logarithm in order to ensure normality.

Scholars have pointed out that economic growth is path dependent, meaning that the previous economic condition of a region may affect subsequent economic growth (Author 1994). We control for economic conditions by including the log of GSP per capita from 2004 to 2008. In order not to overlap with our measure of economic growth, we calculated economic conditions 1 year prior to the base year of the measure of economic growth (e.g., economic condition is the $\log$ of GSP per capita in year $t-2$; economic growth is the log difference in GSP per capita between years $t$ and $t-1)$. This control also minimizes potential problems of reverse causality in our analysis (Hamilton and Nickerson 2003).

The service industry sector is important for economic growth (Fuchs 1968). We measured this variable as the proportion of service firms in the small business population firms per state and per year. Again, the data were obtained from the US Bureau of 
Economic Analysis database. Economic growth may be affected by the financial industry in a region that can facilitate the mobilization of capital (Hicks 1969) and fund entrepreneurial ventures with innovative products and production processes (Schumpeter 1934). We control for the prosperity of the financial industry by using the percentage of GSP accounted for by banks in each state. There is an increasing recognition that health care is becoming more important in regional economies around the USA (Harkavy and Zuckerman 1999). In addition, health care is an institutional concern representing the overall development of social welfare in a region. We therefore control for this using the percentage of GSP accounted for by healthcare. We also control for the potential influence of government administration on economic growth, measured as the percentage of GSP accounted for by public administration expenditures. Indeed, government administration may greatly impact the choice of institutional policy making. Overall, we intentionally choose these variables as they capture the heterogeneity of regions/periods in terms of administrative, institutional, and economic distinctions.

\subsection{Instrumental variables}

It is necessary to control for endogeneity because the results could be affected by reverse causality or latent factors that are not included in the model. We use the following methods to control for endogeneity. Firstly, we use a 1-year time lag between the measurement of our dependent and other variables in our panel regression. This partially ensures that the direction of the causal relationship is as we hypothesize, hence reducing the odds that the focal variable (family business) may be endogenously driven (Hamilton and Nickerson 2003). Secondly, noting that the dependent variable is measured as the log difference of GSP per capita between $t$ and $t-1$, we intentionally include the $\log$ of GSP per capita in $t-2$ as a control, which further reduces the impact of endogeneity by guarding against the possibility of reverse causality (Hamilton and Nickerson 2003). Lastly, we select instrumental variables that are strongly related to the independent variable (family SMEs prevalence) but unrelated to the dependent variable (economic growth). We select three instrumental variables for this study. First, we include the change in divorce rate based on provisional counts of divorces by state of occurrence, obtained from National Vital Statistics System. This variable is measured as change in the percentage of divorced individuals in the population. Second, we include migration, calculated as the proportion of new migrants into a state to the overall population for each year. We obtained data on migration from the US Census. Third, we include ethnicity, measured as the proportion of white non-Hispanics per state and per year as a control variable, obtained from the US Census. All three variables capture factors related to the types and stability of families in a given region and should therefore be more strongly correlated with the proportion of family firms in a region than the economic growth of a region.

Following Hamilton and Nickerson (2003), we use a two-stage regression approach with instrumental variables. In the first stage, the three instruments and controls were used to estimate the prevalence of family SMEs. In the second stage, the dependent variable (economic growth) was regressed against the predicted family SMEs prevalence obtained in the first stage, the squared value of that variable, and the control variables.

\section{Results}

The approach to measuring the dependent, independent, and control variables used in this study is summarized in Table 2. The means and standard deviations of each variable as well as the correlation matrix are shown in Table 3.

Due to the longitudinal structure of data, ordinary least square regression may provide biased estimates. Compared to ordinary least square regression, panel regression is preferred to analyze longitudinal data, as it provides a better explanation concerning causal relationships from past to present. Fixed effects panel regression can control for unobservable cross-sectional characteristics (Frye 2004), and it has been applied in previous family business studies (Chen and Hsu 2009). Hence, we control for fixed effects of cross sections-namely states-in this analysis. The Hausman test revealed that there was no significant difference between fixed- and random-effect models (Chi-square $=63.23, p$ value $<0.001$ ). Thus, we used the more robust fixed-effect panel regression for our analysis. We also used the Huber-White sandwich estimator (clustered at the state level) to control for 
Table 2 Definition of variables and data source

\begin{tabular}{|c|c|c|c|c|}
\hline Name & Definition & Unit & Source & Period \\
\hline $\begin{array}{l}\text { Economic } \\
\text { development }\end{array}$ & $\begin{array}{l}\text { Log difference of gross state product per capita } \\
\text { (measured in thousand dollars) in each state } \\
\text { between } t \text { and } t-1\end{array}$ & $\begin{array}{l}\text { Log difference in thousand dollars } \\
\text { (percentage change in GSP per } \\
\text { capita is used in robustness test) }\end{array}$ & $\begin{array}{l}\text { US Bureau } \\
\text { of } \\
\text { Economic } \\
\text { Analysis }\end{array}$ & 2006-2010 \\
\hline $\begin{array}{l}\text { Family SME } \\
\text { prevalence }\end{array}$ & $\begin{array}{l}\text { Proportion of family SMEs among SBDC } \\
\text { respondents in each state in year } t-1 \text {. } \\
\text { Family SMEs are operationalized as any firm } \\
\text { with more than } 50 \% \text { family ownership, at } \\
\text { least one family manager, and the intention } \\
\text { of intra-family succession. We also use } \\
\text { family } 50 \% \text { and } 100 \% \text { ownership cutoffs } \\
\text { for robustness tests }\end{array}$ & Percentage & SBDC & 2005-2009 \\
\hline Population & Population per state in year $t-1$ & Logged number & US Census & 2005-2009 \\
\hline $\begin{array}{l}\text { Economic } \\
\text { conditions }\end{array}$ & $\begin{array}{l}\text { Log of gross state product per capita in each } \\
\text { state in year } t-2\end{array}$ & Log of thousand dollars per capita & $\begin{array}{l}\text { US Bureau } \\
\text { of } \\
\text { Economic } \\
\text { Analysis }\end{array}$ & 2004-2008 \\
\hline $\begin{array}{l}\text { Service } \\
\text { industry }\end{array}$ & $\begin{array}{l}\text { Proportion of service firms per state in year } \\
t-1\end{array}$ & Percentage & $\begin{array}{l}\text { US Bureau } \\
\text { of } \\
\text { Economic } \\
\text { Analysis }\end{array}$ & 2005-2009 \\
\hline $\begin{array}{l}\text { Financial } \\
\text { industry }\end{array}$ & $\begin{array}{l}\text { Proportion of GSP accounted for by banks in } \\
\text { each state in year } t-1\end{array}$ & Percentage & $\begin{array}{l}\text { US Bureau } \\
\text { of } \\
\text { Economic } \\
\text { Analysis }\end{array}$ & 2005-2009 \\
\hline $\begin{array}{l}\text { Healthcare } \\
\text { Service }\end{array}$ & $\begin{array}{l}\text { Proportion of GSP accounted for by healthcare } \\
\text { in each state in year } t-1\end{array}$ & Percentage & $\begin{array}{l}\text { US Bureau } \\
\text { of } \\
\text { Economic } \\
\text { Analysis }\end{array}$ & 2005-2009 \\
\hline $\begin{array}{l}\text { Government } \\
\text { administration }\end{array}$ & $\begin{array}{l}\text { Proportion of GSP accounted for by } \\
\text { government administration expense in each } \\
\text { state in year } t-1\end{array}$ & Percentage & $\begin{array}{l}\text { US Bureau } \\
\text { of } \\
\text { Economic } \\
\text { Analysis }\end{array}$ & 2005-2009 \\
\hline \multicolumn{5}{|c|}{ Instrumental variables } \\
\hline $\begin{array}{l}\text { Change in } \\
\text { divorce rate }\end{array}$ & $\begin{array}{l}\text { Difference of divorce rate in each state } \\
\text { between year } t-1 \text { and } t-2\end{array}$ & Difference of Percentage & $\begin{array}{l}\text { National } \\
\text { Vital } \\
\text { Statistics } \\
\text { System }\end{array}$ & 2005-2009 \\
\hline Migration rate & $\begin{array}{l}\text { Percentage of population that migrated into } \\
\text { each state in year } t-1\end{array}$ & Percentage & US Census & 2005-2009 \\
\hline Ethnicity & $\begin{array}{l}\text { Proportion of non-Hispanic white population } \\
\text { over all population in each state in year } t-1\end{array}$ & Percentage & US Census & 2005-2009 \\
\hline
\end{tabular}

potential serial correlation and heteroscedasticity (Arellano 2003).

As mentioned above, we present our main analysis using family ownership, family management, and intra-family succession intention as the criteria to classify family firms, and 50 minimum responses per state and per year as the cutoff to calculate the ratio of family SMEs per state and per year. We relax these restrictions in the robustness tests. Table 4 shows the results of the two-stage regression analysis. In the first stage, change in divorce rate $(B=-4.90, p<0.01)$, migration rate $(B=-4.22, p<0.05)$, and ethnicity 
Table 3 Descriptive and correlation analysis ${ }^{\mathrm{a}}$

\begin{tabular}{|c|c|c|c|c|c|c|c|c|c|c|}
\hline & Mean & S.D. & 1 & 2 & 3 & 4 & 5 & 6 & 7 & 8 \\
\hline 1. Economic growth & 0.03 & 0.03 & 1.00 & & & & & & & \\
\hline 2. Family SME prevalence $\%^{\mathrm{a}}$ & 43.69 & 10.92 & 0.01 & 1.00 & & & & & & \\
\hline 3. Population & 15.03 & 0.99 & -0.17 & -0.11 & 1.00 & & & & & \\
\hline 4. Economic condition & 3.71 & 0.26 & -0.12 & -0.06 & -0.24 & 1.00 & & & & \\
\hline 5. Service industry $\%$ & 63.14 & 4.18 & 0.08 & 0.00 & -0.14 & 0.20 & 1.00 & & & \\
\hline 6. Financial industry $\%$ & 3.82 & 3.01 & -0.01 & -0.03 & -0.01 & 0.12 & 0.03 & 1.00 & & \\
\hline 7. Healthcare expenditure $\%$ & 7.18 & 1.41 & -0.07 & -0.01 & 0.03 & -0.16 & -0.39 & -0.03 & 1.00 & \\
\hline 8. Government administration $\%$ & 2.39 & 0.72 & -0.03 & 0.00 & -0.09 & 0.09 & 0.26 & -0.20 & -0.07 & 1.00 \\
\hline
\end{tabular}

All correlations above $10.11 \mathrm{l}$ are significant at 0.10 or lower for a two-tailed test

Descriptive and correlation analyses are under the condition of 50 minimum firm responses as the cutoff

${ }^{a}$ At least $50 \%$ family ownership, at least one family manager, and intention for intra-family succession as the classification criteria to identify family business

Table 4 Fixed-effect regression analysis $(50$ minimum firm responses as the cutoff)

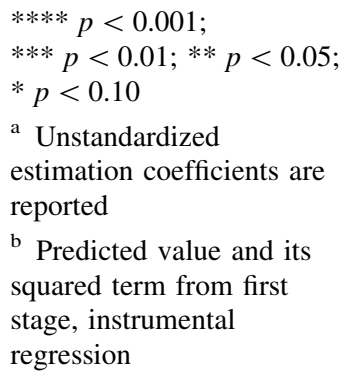

\begin{tabular}{|c|c|c|}
\hline Dependent variable & $\begin{array}{l}\text { 1st Stage } \\
\text { Family SMEs prevalence }\end{array}$ & $\begin{array}{l}\text { 2nd Stage } \\
\text { Economic growth }\end{array}$ \\
\hline \multicolumn{3}{|l|}{ Independent variables } \\
\hline Family SMEs prevalence ${ }^{\mathrm{a}}$ & & $0.01112 * *$ \\
\hline Family SMEs prevalence square ${ }^{\mathrm{b}}$ & & $-0.00013 * * *$ \\
\hline \multicolumn{3}{|l|}{ Controls } \\
\hline Population & $200.68 * * * *$ & -0.22 \\
\hline Economic condition & 0.84 & $-0.29 *$ \\
\hline Service industry & $0.27 * * * *$ & 0.00 \\
\hline Financial industry & $-0.27 * *$ & -0.0006 \\
\hline Healthcare service & -0.41 & 0.001 \\
\hline Government administration & -1.30 & -0.003 \\
\hline \multicolumn{3}{|l|}{ Instrumental variables } \\
\hline Change in divorce rate & $-4.90 * * *$ & \\
\hline Migration rate & $-4.22 * *$ & \\
\hline Ethnicity & $3.66 * *$ & \\
\hline Sample size & 121 & 121 \\
\hline Cross section & 45 & 45 \\
\hline Period & 5 & 5 \\
\hline Within $\mathrm{R}^{\wedge} 2$ & 0.09 & 0.49 \\
\hline F-statistics & $1.35 * * * *$ & $2.44 * * * *$ \\
\hline
\end{tabular}

( $B=3.66, p<0.05)$ prove to be good predictors of the prevalence of family SMEs. Taken together, this suggests that our selection of instrumental variables is appropriate to control for endogeneity in this analysis.

The second stage uses the predicted family business prevalence obtained from the first stage and its squared term as the independent variables. Overall, the within
$\mathrm{R}^{2}$ is 0.49 , and the model is significant (log likelihood $=536.44, \quad$ F-statistic $=2.44, \quad p<0.001)$. Among the control variables, past economic status $(B=-0.29 ; p<0.10)$ has a significant negative relationship with regional economic growth. In support of $\mathrm{H} 1$, the family SME prevalence variable is positive and significant $(B=0.01112 ; p<0.05)$, 
Table 5 Fixed-effect regression analysis

\begin{tabular}{|c|c|c|c|c|c|}
\hline \multirow[t]{2}{*}{ Dependent variable } & \multicolumn{2}{|c|}{$\begin{array}{l}\text { Log difference of GSP per } \\
\text { capita between } t \text { and } t-1\end{array}$} & \multicolumn{3}{|c|}{$\begin{array}{l}\text { Percentage change in GSP } \\
\text { per capital from } t-1 \text { to } t\end{array}$} \\
\hline & Response $\geq 40$ & Response $\geq 60$ & Response $\geq 40$ & Response $\geq 50$ & Response $\geq 60$ \\
\hline \multicolumn{6}{|l|}{ Independent variables } \\
\hline Family SME prevalence ${ }^{a}$ & $0.01351 * * *$ & $0.01827 * * * *$ & $1.351 * * * *$ & $1.120 * * *$ & $1.833 * * * *$ \\
\hline $\begin{array}{l}\text { Family SME prevalence square } \\
\text { Controls }\end{array}$ & $-0.00016^{* * *}$ & $-0.00024 * * * *$ & $-0.016^{* * * *}$ & $-0.012 * * *$ & $-0.0240 * * *$ \\
\hline Population & -0.21 & 0.66 & -23.90 & -25.16 & 64.28 \\
\hline Economic condition & $-0.24 *$ & $-0.48 * * * *$ & $-24.65^{*}$ & $-28.74 * *$ & $-49.30 * * * *$ \\
\hline Service industry & 0.00 & 0.00 & 0.04 & 0.08 & -0.04 \\
\hline Financial industry & -0.001 & $-0.002 *$ & -0.06 & -0.06 & $-0.16^{*}$ \\
\hline Healthcare service & -0.0003 & $-0.002 *$ & -0.03 & -0.09 & $-0.26^{*}$ \\
\hline Government administration & -0.004 & -0.01 & -0.39 & -0.31 & -0.69 \\
\hline Sample size & 135 & 100 & 135 & 121 & 100 \\
\hline Cross section & 45 & 42 & 45 & 45 & 42 \\
\hline Period & 5 & 5 & 5 & 5 & 5 \\
\hline Within $\mathrm{R}^{\wedge} 2$ & 0.37 & 0.67 & 0.49 & 0.49 & 0.67 \\
\hline F-statistics & $2.81 * * * *$ & $3.57 * * * *$ & $2.86^{* * * * *}$ & $2.49 * * * *$ & $3.66 * * * *$ \\
\hline
\end{tabular}

Unstandardized estimation coefficients are reported

**** $p<0.001$; *** $p<0.01$; ** $p<0.05$; * $p<0.10$

${ }^{a}$ Predicted value from first stage, instrumental regression

while its square is negative and significant $(B=-0.00013 ; p<0.01) .^{2}$ The inflection point of the inverted U-shaped relationship between family firm ratio and regional economic growth is found at $42.8 \%[0.01112 /(2 * 0.00013)]$, which is calculated based on the first derivative of the estimate of family SME prevalence and family SME prevalence squared.

\subsection{Robustness test}

As mentioned above, we conducted various robustness tests to ensure that our results were not an artifact of the restrictions we placed in the sample. First, we altered the number of minimum respondents per state. As shown in Table 5, when using 40 or 60 respondents as the cutoff points, the results are similar to our main analysis and supportive of the hypothesized inverted $\mathrm{U}$-shaped relationship between the prevalence of

\footnotetext{
${ }^{2}$ The small magnitudes of these two coefficients are due to the choice of DV (log difference). When changing DV into the percentage difference, magnitudes of family SME proportion as well as its square term become much larger (Table 4).
}

family SMEs and regional economic growth. Second, we changed the measure of economic growth from the log difference of GSP per capita to the percentage change in GSP per capita between $t$ and $t-1$. As shown in Table 5, the results using minimum samples of 40, 50, and 60 firms are consistent with our main analysis. ${ }^{3}$ We also use the unadjusted value of GSP per capita as the dependent variable. ${ }^{4}$ In this regard, both GSP per capita in $t-1$ and $t-2$ are included as control variables. Again the results are consistent with our primary findings. Third, we tested our base model using the actual rather than predicted values of the prevalence of family SMEs. Again, for both economic growth measures (log difference or percentage change in GSP per capita) with the minimum cutoff of 40, 50, and 60 , regression results are consistent with our

\footnotetext{
3 As above, to control for endogeneity we use the predicted values of the family SME prevalence variable after regressing it against the three instrumental variables and controls (Table 3, 1st stage).

4 The results of the robustness test and tests below are available upon request from the second author.
} 
primary analysis. Fourth, as noted before, we use thresholds of 50 and $100 \%$ family ownership as the sole method of classifying family firms. This approach emphasizes the power, authority, and legitimacy associated with family ownership (Carney 2005), but overlooks that family involvement in general management and intention for intra-family succession also make an impact on the nature of the business. Nevertheless, for both measures of economic growth using the minimum cutoffs of 40,50 , and 60 responses per state, the results are again consistent with our main analysis.

\section{Discussion}

In this paper, we attempt to explore how the prevalence of small- to medium-size family firms affects economic growth. We suggest that the proportion of family SMEs will have an inverted U-shaped relationship with economic growth. Our findings support the hypothesis that there is an optimum level of family SMEs in a local economy. Up to that point, which our analysis suggests to be about $42.8 \%$ of the SME population, an increasing proportion of family firms have a positive influence on economic growth. However, beyond that point, more and more family firms in the economy appear to reduce economic growth. This result suggests that a balanced combination of family and non-family SMEs can best maximize economic growth.

We build our arguments upon the knowledge-based view of economic growth, i.e., how heterogeneity may increase knowledge asymmetry among market players, thereby facilitating knowledge spillover and economic growth. We contribute to the economic growth and small business literature by further exploring how governance archetypes may become one dimension of heterogeneity that stimulates economic growth. In addition, we also contribute to the family business literature by providing evidence that an optimal level of family SMEs stimulates economic growth. While previous studies largely focused on how family firms contribute to the economy (employment, GDP, etc.), to the best of our knowledge we are the first to explore how they affect the growth of the economy. Altogether, these contributions provide a more granular understanding of the role of family firms in economic growth.
Aside from its contributions, our study has several limitations, which not only represent the boundaries of its insights, but also provide opportunities for future research. First, we examined the impact of the proportion of small- to medium-size family firms on economic growth. Indeed, owing to the fact that there is no existing database regarding the prevalence of family business in the USA, our study aggregates firmlevel data from the annual survey of SBDC clients between 2005 and 2009 in the USA. However, despite the size of our sample in aggregate, we rely on a relatively small number of firms per state and per year to make our estimates of the prevalence of family firms. Furthermore, we do not include large firms, which may be characterized by different behavioral dynamics and outcomes. For example, innovative activities and access to skilled human resources are different between small- and large-sized companies (Freel 2000; Tan et al. 2009; Tether 1998). Morck and Yeung (2004) also suggest that, in opposition to the economic well-being of society, very large family firms possess the power and inclination to engage in political rent-seeking, which tends to reduce rather than increase economic growth. Future scholars are therefore encouraged to take into account the roles of family and non-family firms of varying sizes when investigating how family involvement affects economic growth.

Second, in recent years, family business researchers have increasingly recognized that family firms are heterogeneous (e.g., Chua et al. 2012; Westhead and Howorth 2007). However, the nature of our data made it difficult for us to differentiate between different types of family firms in terms of their effects on economic growth. Research is therefore needed to explore how different types of family firms may contribute to economic growth. Family involvement exerted through different ownership and management structures can lead to diverse behavior and firm performance (De Massis et al. 2013b), and this may, in turn, affect economic growth. For instance, prior studies show that founder-led firms (some of which may also be family firms) perform better than both late-generation family firms and non-family firms (Miller et al. 2007). Similarly, other work indicates that the proactive attitude of family firms changes over time as a function of firm age (De Massis et al. 2014). Moreover, as emphasized throughout this paper and in the family business literature in general, family firms 
are characterized by the coexistence of different sets of economic and noneconomic goals (Chrisman et al. 2012). How the proportion of family firms that are driven primarily by economic versus noneconomic goals affects economic growth deserves further investigation.

Third, our study explores the impact of the proportion of family SMEs on economic growth in the USA. In general, we believe the basic tenet of the study-the inverted U-shaped relationship between family business prevalence and economic growth-should apply to all economies. Nevertheless, differences in legal structures, stages of economic development, cultures, and other factors may influence both the prevalence and economic impact of family firms (Gedajlovic et al. 2012; Morck and Yeung 2003, 2004). It would therefore be desirable to replicate our study across different countries.

Fourth, following Chang et al. (2008), we use states as the basic unit in this longitudinal study. Nevertheless, there may be important variations within states such as the distinction between rural and metropolitan areas. Thus, using alternative units of analysis might offer other important insights.

Finally, creation and generation of economic growth are among the top priorities of many governments worldwide. This study has therefore strong implications for policy making. Programs and funding that promote entrepreneurship and economic growth in both the developed and developing countries are increasing (Acs and Szerb 2007; Audretsch et al. 2015). However, the macroeconomic policies driving support and investment in small and medium enterprises appear to be based on the assumption that firms of comparable size have similar developmental needs and potentials. As a consequence, public policy programs usually segment potential firms according to size (employees and sales turnover) and/or industry. In effect, existing support programs lump family and non-family firms together into an "SME sector". This study suggests that family SMEs are distinct from nonfamily firms in economically significant ways. Our theory and evidence on the impact of the prevalence of family SMEs on economic growth is a first step toward alerting policy makers of the need for public policy to take into account the idiosyncratic characteristics and challenges of a very prevalent and relevant form of business organization. For example, family firms pursue a variety of economic and noneconomic goals that sometimes conflict and sometimes are complementary (Kotlar and De Massis 2013). The better these goals are understood and articulated, the better policy makers will be able to provide support programs for family business growth. If the current system fails to recognize the importance of small- to medium-size family firms and their idiosyncratic needs, economic growth could be adversely affected.

\section{Conclusion}

In sum, this study draws on the family business and knowledge-based literatures of economic growth to explain the impact of the prevalence of family firms on economic growth. The results show an inverted U-shaped relationship between the proportion of small- and medium-sized family firms and economic growth at regional level. Consistent with the idea that heterogeneity stimulates innovation and economic growth (Knott 2003) and a variety of firms of different types are needed to expand and transform the productive potential of a regional economy (Wennekers and Thurik 1999), our study shows that a balanced mix of family firms and non-family firms is better than either a dominant portion of family firms or portion of nonfamily firms. Since this has both theoretical and practical value, further work is needed to study how family firms impact their local economies, particularly as political leaders argue over effective policies to stimulate economic growth during times of recession. We hope our study stimulates future research on this complex, yet important topic.

\section{Compliance with ethical standards}

The authors declare that their manuscript is compliant with ethical standards and they have no conflict of interest.

\section{References}

Acs, Z. J., Braunerhjelm, P., Audretsch, D. B., \& Carlsson, B. (2009). The knowledge spillover theory of entrepreneurship. Small Business Economics, 32, 15-30.

Acs, Z. J., Brooksbank, D., O'Gorman, C, Pickernell, D. \& Terjesen, S. (2007). The knowledge spillover theory of entrepreneurship and foreign direct investment. Jena Economic Research Papers, 2007-059.

Acs, Z. J., \& Szerb, L. (2007). Entrepreneurship, economic growth and public policy. Small Business Economics, 28(2-3), 109-122. 
Agarwal, R., Audretsch, D. B., \& Sarkar, M. B. (2007). The process of creative construction: Knowledge spillovers, entrepreneurship, and economic growth. Strategic Entrepreneurship Journal, 1(3/4), 263-286.

Agarwal, R., Echambadi, R., April, F., \& Sarkar, M. (2004). Knowledge transfer through inheritance: Spin-out generation, development and performance. Academy of Management Journal, 47, 501-522.

Aldrich, H. E., \& Cliff, J. E. (2003). The pervasive effects of family on entrepreneurship: Toward a family embeddedness perspective. Journal of Business Venturing, 18(5), 573-596.

Arellano, M. (2003). Panel data econometrics: Advanced texts in econometrics. Oxford: Oxford University Press.

Arregle, J.-L., Hitt, M. A., Sirmon, D. G., \& Very, P. (2007). The development of organizational social capital: Attributes of family firms. Journal of Management Studies, 44(1), 73-95.

Astrachan, J. H., \& Shanker, M. C. (2003). Family businesses' contribution to the U.S. economy: A closer look. Family Business Review, 16(3), 211-219.

Audretsch, D. B. (2007). The entrepreneurial society. Oxford: Oxford University Press.

Audretsch, D. B., \& Feldman, M. P. (1996). R\&D spillovers and the geography of innovation and production. American Economic Review, 86(3), 630-640.

Audretsch, D. B., Heger, D., \& Veith, T. (2015). Infrastructure and entrepreneurship. Small Business Economics, 44(2), 219-230.

Audretsch, D. B., Keilbach, M. C., \& Lehmann, E. E. (2006). Entrepreneurship and economic growth. Oxford: Oxford University Press.

Author, W. B. (1994). Increasing returns and path dependence in the economy. Ann Arbor, MI: The University of Michigan Press.

Barro, R. J. (1991). Economic growth in a cross section of countries. The Quarterly Journal of Economics, 106(2), 407-443.

Becchetti, L., \& Trovato, G. (2002). The determinants of growth for small and medium sized firms: The role of the availability of external finance. Small Business Economics, 19(4), 291-306.

Benedict, B. (1968). Family firms and economic development. Southwestern Journal of Anthropology, 24(1), 1-19.

Bennedsen, M., Perez-Gonzalez, F., \& Wolfenzon, D. (2010). The governance of family firms. In K. H. Baker \& R. Anderson (Eds.), Corporate governance: A synthesis of theory, research, and practice (pp. 371-389). Hoboken: Wiley.

Bjuggren, C. M., Johansson, D., \& Sjögren, H. (2011). A note on employment and gross domestic product in Swedish family-owned businesses: A descriptive analysis. Family Business Review, 24(4), 362-371.

Brannon, D. L., Wiklund, J., \& Haynie, J. M. (2013). The varying effects of family relationships in entrepreneurial teams. Entrepreneurship Theory and Practice, 37(1), 107-132.

Cabrera-Suárez, K., De Saá-Pérez, P., \& García-Almeida, D. (2001). The succession process from a resource-and knowledge-based view of the family firm. Family Business Review, 14(1), 37-46.
Carney, M. (2005). Corporate governance and competitive advantage in family-controlled firms. Entrepreneurship Theory and Practice, 29(3), 249-265.

Chang, E. P. C., Chrisman, J. J., Chua, J. H., \& Kellermanns, F. K. (2008). Regional economy as a determinant of the prevalence of family firms in the United States: A preliminary report. Entrepreneurship Theory and Practice, 32(3), 559-573.

Chen, H.-L., \& Hsu, W.-T. (2009). Family ownership, board independence, and R\&D investment. Family Business Review, 22(4), 347-362.

Chrisman, J. J., Chua, J. H., De Massis, A., Frattini, F., \& Wright, M. (2015). The ability and willingness paradox in family firm innovation. Journal of Product Innovation Management, 32(3), 310-318.

Chrisman, J. J., Chua, J. H., \& Litz, R. (2004). Comparing the agency costs of family and non-family firms: Conceptual issues and exploratory evidence. Entrepreneurship Theory and Practice, 28(4), 335-354.

Chrisman, J. J., Chua, J. H., Pearson, A. W., \& Barnett, T. (2012). Family involvement, family influence, and familycentered non-economic goals in small firms. Entrepreneurship Theory and Practice, 36(2), 267-293.

Chrisman, J. J., Chua, J. H., \& Steier, L. P. (2011). Resilience of family firms: An introduction. Entrepreneurship Theory and Practice, 35(6), 1107-1119.

Chrisman, J. J., \& Patel, P. J. (2012). Variations in R\&D investments of family and non-family firms: Behavioral agency and myopic loss aversion perspectives. Academy of Management Journal, 55, 976-997.

Chrisman, J. J., Van Deusen, C., \& Anyomi, S. M. K. (1992). Population growth and regional economy: An empirical analysis of business formation and job generation in the retail sector. Entrepreneurship and Regional Development, 4(4), 339-355.

Chua, J. H., Chrisman, J. J., \& Sharma, P. (1999). Defining the family business by behavior. Entrepreneurship Theory and Practice, 23(4), 19-39.

Chua, J. H., Chrisman, J. J., Steier, L. P., \& Rau, S. B. (2012). Sources of heterogeneity in family firms: An introduction. Entrepreneurship Theory and Practice, 36, 1103-1113.

Classen, N., Carree, M., Van Gils, A., \& Peters, B. (2014). Innovation in family and non-family SMEs: An exploratory analysis. Small Business Economics, 42(3), 595-609.

Colombo, M. G., De Massis, A., Piva, E., Rossi-Lamastra, C., \& Wright, M. (2014). Sales and employment changes in entrepreneurial ventures with family ownership: Empirical evidence from high-tech industries. Journal of Small Business Management, 52(2), 226-245.

De Massis, A., Chirico, F., Kotlar, J., \& Naldi, L. (2014). The temporal evolution of proactiveness in family firms: The horizontal s-curve hypothesis. Family Business Review, 27(1), 35-50.

De Massis, A., Frattini, F., \& Lichtenthaler, U. (2013a). Research on technological innovation in family firms: Present debates and future directions. Family Business Review, 26(1), 10-31.

De Massis, A., Kotlar, J., Campopiano, G., \& Cassia, L. (2013b). The impact of family involvement on SMEs' performance: 
Theory and evidence. Journal of Small Business Management. doi:10.1111/jsbm.12093.

Donckels, R., \& Frochlich, E. (1991). Are family businesses really different? European experiences from STRATOS. Family Business Review, 4(2), 149-160.

Dyer, W. G. (2003). The family: The missing variable in organizational research. Entrepreneurship Theory and Practice, 27(4), 401-416.

Fama, E. F., \& Jensen, M. C. (1983). Agency problems and residual claims. Journal of Law and Economics, 26(2), 327-349.

Freel, M. S. (2000). Strategy and structure in innovative manufacturing SMEs: The case of an English region. Small Business Economics, 15(1), 27-45.

Frye, M. B. (2004). Equity-based compensation for employee: Firm performance and determinants. Journal of Financial Research, 27(1), 31-54.

Fuchs, V. (1968). The service economy. New York: Columbia University Press.

Gedajlovic, E., \& Carney, M. (2010). Markets, hierarchies, and families: Toward a transaction cost theory of the family firm. Entrepreneurship Theory and Practice, 34(6), 1145-1171.

Gedajlovic, E., Carney, M., Chrisman, J. J., \& Kellermanns, F. W. (2012). The adolescence of family firm research: Taking stock and planning for the future. Journal of Management, 38(4), 1010-1037.

Gersick, K. E., Davis, J. A., Hampton, M. M., \& Lansberg, I. (1997). Generation to generation: Life cycles of the family business. Boston, MA: Harvard Business School Press.

Gómez-Mejía, L. R., Cruz, C., Berrone, P., \& De Castro, J. (2011). The bind that ties: Socioemotional wealth preservation in family firms. Academy of Management Annuals, 5, 653-707.

Gómez-Mejia, L. R., Makri, M., \& Larraza-Kintana, M. (2010). Diversification decisions in family-controlled firms. Journal of Management Studies, 47(2), 223-252.

Habbershon, T. G., \& Williams, M. L. (1999). A resource-based framework for assessing the strategic advantages of family firms. Family Business Review, 12(1), 1-25.

Hamilton, B. H., \& Nickerson, J. A. (2003). Correcting for endogeneity in strategic management research. Strategic Organization, 1(1), 51-78.

Harkavy, I., \& Zuckerman, H. (1999). Eds and Meds: Cities' Hidden Assets. Washington, DC: The Brookings Institution Survey Series.

Hicks, J. (1969). A theory of economic history. Oxford: Clarendon Press.

Hoopes, D. G., Madsen, T. L., \& Walker, G. (2003). Why is there a resource-based view? Toward a theory of competitive heterogeneity. Strategic Management Journal, 24, 889-902.

James, H. (1999). Owners as managers, extended horizon and the family firm. International Journal of the Economics of Business, 6, 41-56.

Kanuk, L., \& Berenson, C. (1975). Mail surveys and response rate: A literature review. Journal of Marketing Research, 12(4), 440-453.

Khalaf, S., \& Shwayri, E. (1966). Family firms and industrial development: The Lebanese case. Economic Development and Cultural Change, 15(1), 59-69.
Knott, A. M. (2003). Persistent heterogeneity and sustainable innovation. Strategic Management Journal, 24(8), 687-705.

König, A., Kammerlander, N., \& Enders, A. (2013). The family innovator's dilemma: How family influence affects the adoption of discontinuous technologies by incumbent firms. Academy of Management Review, 38(3), 418-441.

Kotlar, J., \& De Massis, A. (2013). Goal setting in family firms: Goal diversity, social interactions, and collective commitment to family-centered goals. Entrepreneurship Theory and Practice, 37(6), 1263-1288.

Kotlar, J., De Massis, A., Fang, H., \& Frattini, F. (2014a). Strategic reference points in family firms. Small Business Economics, 43(3), 597-619.

Kotlar, J., Fang, H. C., De Massis, A., \& Frattini, F. (2014b). Profitability goals, control goals, and the R\&D investment decisions of family and nonfamily firms. Journal of Product Innovation Management, 31(6), 1128-1145.

La Porta, R., Lopez-de-Silanes, F., Shleifer, A., \& Vishny, R. (1999). Corporate ownership around the world. Journal of Finance, 54(2), 471-517.

Le Breton-Miller, I., \& Miller, D. (2011). Commentary: Family firms and the advantage of multitemporality. Entrepreneurship Theory and Practice, 35(6), 1171-1177.

Lumpkin, G. T., \& Brigham, K. H. (2011). Long-term orientation and intertemporal choice in family firms. Entrepreneurship Theory and Practice, 35(6), 1179-1197.

Miller, D., Le Breton-Miller, I., Lester, R. H., \& Cannella, A. A, Jr. (2007). Are family firms really superior performers? Journal of Corporate Finance, 13(5), 829-858.

Morck, R. K., Stangeland, D. A., \& Yeung, B. (1998). Inherited wealth, corporate control and economic growth. The William Davidson Institute Working Paper Number 209.

Morck, R., \& Yeung, B. (2003). Agency problems in large family business groups. Entrepreneurship Theory and Practice, 27(4), 367-382.

Morck, R., \& Yeung, B. (2004). Family control and the rentseeking society. Entrepreneurship Theory and Practice, 28(4), 391-409.

Oppenheim, A. N. (1966). Questionnaire design and attitude measurement. New York: Free Press.

Pollak, R. A. (1985). A transaction cost approach to families and households. Journal of Economic Literature, 23(2), 581-608.

Rothwell, R., \& Zegveld, W. (1982). Innovation and the small and medium sized firm. University of Illinois at UrbanaChampaign's Academy for Entrepreneurial Leadership Historical Research Reference in Entrepreneurship.

Schepers, J., Voordeckers, W., Steijvers, T., \& Laveren, E. (2014). The entrepreneurial orientation-performance relationship in private family firms: The moderating role of socioemotional wealth. Small Business Economics, 43(1), 39-55.

Schulze, W. S., \& Gedajlovic, E. R. (2010). Whither family business? Journal of Management Studies, 47(2), 191-204.

Schulze, W. S., Lubatkin, M. H., Dino, R. N., \& Buchholtz, A. K. (2001). Agency relationships in family firms: Theory and evidence. Organization Science, 12(2), 99-116.

Schumpeter, J. (1934). The theory of economic development. Cambridge: Harvard University Press.

Shanker, M. C., \& Astrachan, J. H. (1996). Myths and realities: Family businesses' contribution to the US economy-A 
framework for assessing family business statistics. Family Business Review, 9(2), 107-123.

Sharma, P., Chrisman, J. J., \& Chua, J. H. (1997). Strategic management of the family business: Past research and future challenges. Family Business Review, 10(1), $1-35$.

Sirmon, D. G., \& Hitt, M. A. (2003). Managing resources: Linking unique resources, management, and wealth creation in family firms. Entrepreneurship Theory and Practice, 27(4), 339-358.

Tagiuri, R., \& Davis, J. (1996). Bivalent attributes of the family firm. Family Business Review, 9(2), 199-208.

Tan, J., Fischer, E., Mitchell, R., \& Phan, P. (2009). At the center of the action: Innovation and technology strategy research in the small business setting. Journal of Small Business Management, 47(3), 233-262.

Tether, B. S. (1998). Small and large firms: Sources of unequal innovations? Research Policy, 27(7), 725-745.

Thurik, R., \& Wennekers, S. (2004). Entrepreneurship, small business and economic growth. Journal of Small Business and Enterprise Development, 11(1), 140-149.

Wennekers, S., \& Thurik, R. (1999). Linking entrepreneurship and economic growth. Small Business Economics, 13(1), 27-56.

Westhead, P., \& Howorth, C. (2007). Types of private family firms: An exploratory conceptual and empirical analysis. Entrepreneurship and Regional Development, 19(5), 405-431. 